\title{
TOXICITY AND PHYSIOLOGICAL EFFECT OF ESSENTIAL OIL OF ARTEMISIA ANNUA (LABIATAE) ON AGRIOLIMAX AGRESTIS L. (STYLOMMATOPHORA: LIMACIDAE)
}

\author{
Fereshteh Amirmohammadi, Jalal Jalali Sendi ${ }^{*}$, Arash Zibaee
}

Department of Plant Protection, College of Agriculture, University of Guilan, Rasht, 41335 Iran

Received: June 21, 2011

Accepted: November 28, 2011

\begin{abstract}
Essential oil of Artemisia annua L. was investigated to find out its toxicity and physiological aspects on the slug Agriolimax agrestis, in controlled conditions $\left(8 \pm 1^{\circ} \mathrm{C}, 75 \pm 5 \mathrm{RH}\right.$ and $\left.14: 10 \mathrm{LD}\right)$. The slugs received different concentrations of essential oil treated radish leaves in methanol, while the control received methanol alone. $\mathrm{LC}_{10}, \mathrm{LC}_{30}, \mathrm{LC}_{50}$ and $\mathrm{LC}_{90}$ values were estimated at 4.67, 5.3, 5.81, $7.25 \%$, respectively. The effect of the essential oil on some important enzymatic components like; cytochrome P450 monnooxygenase, acid phosphatase, alkaline phosphatase, lipase, amylase and protease were significantly increased compared to the control. These results indicate that the plant Artemisia annua L. not only shows toxicity but also shows some irreversible effect on some important biochemical components and deserves further investigation.
\end{abstract}

Key words: Artemisia annua L., Agriolimax agrestis L., physiological aspects

\section{INTRODUCTION}

Problems associated with the use of synthetic pesticides led researchers to look for natural plant protection compounds such as botanicals, insecticides, and antifeedants. Among the plant families studied, Meliaceae, Asteraceae, Labiateae, Piperaceae and Annonaceae are most promising (Isman 2006). Botanical products are useful tools in many pest management programs because they are effective and especially target the natural enemies of plants. Crops are affected by three main groups: the Limacidae - including the grey field slug (Derocera reticulatum) and its relatives; the Arionidae or round backed slugs - including garden slugs (Arion bortensis and A. desstincus); and the Milacidae or keeled slugs. The grey field slug is the species of greatest importance in arable crops, except for potatoes where damage is usually the result of the activities of keeled and garden slugs. In gardens, the garden slug is the most important species.

Slugs can cause significant damage in a wide range of agricultural and horticultural crops, as well as in gardens (Glen et al. 1991). Agriolimax agrestris L. (Stylommatophora: Limacidae), generally is the pest of cabbage, potato, alfalfa, clover, and some of the other crop plants. This pest is nocturnal and during the light period rests on the backs of leaves. Agriolimax agrestris Linne. are more active in the autumn and spring seasons when the weather is cool and moist. This pest eats different varieties of cabbages and causes severe damage in quality and quantity of crops (Khanjani 2005).

${ }^{*}$ Corresponding address:

jjalali@guilan.ac.ir
The genus Artemisia is a member of the large plant family Asteracea (Compositae) encompassing more than 300 different species of this diverse genus. The species A. annua known as sweet worm wood, grows wild in Europe and America and is planted widely in China, Turkey, Vietnam, Afghanistan and Australia (Bhakani et al. 2001). The plant also grows in northern parts of Iran around paddy fields. Several isolated compounds from this species have been shown to have antimalarial, antibacterial, anti-inflamatory, plant growth regulatory and cytotoxicity (antitomur) activities (Bhakani et al. 2001). Several studies have reported the insecticidal effects of sweet worm wood (Acher et al. 1993; Schmutterer et al. 1995; Rao et al. 1999; Jalali et al. 2002; Jalali et al. 2005; Isman 2006). There has been no report on its effects on Agriolimax agrestis (Limacidae). In the present study we have tried to elucidate the effect of the essential oil of A. annua on toxicity, and the possible mechanisms involved in its effect.

\section{MATERIALS AND METHODS}

\section{Laboratory mass culture of $A$. agrestis}

The slugs were collected in the vicinity of Rasht (Taremseshanbeh) in Guilan Province, Iran from radish fields. Only active animals of healthy appearance with no signs of stress or parasitical infection were used. Fortyfive slugs which were 2 centimeters long were randomly selected and placed in $10 \times 20 \mathrm{~cm}$ transparent container 
in which the lid had holes for aeration. These containers were maintained in the laboratory at $8 \pm 1^{\circ} \mathrm{C}$; $14: 10 \mathrm{LD}$; $75 \pm 5 \%$ RH.

\section{Essential oil preparation}

Plants were collected from paddy fields in northern Iran in mid May 2010. They were dried in the shade and made into a fine powder with the help of a hand mortar. Next, $50 \mathrm{~g}$ of dried herb powder was briefly mixed with $750 \mathrm{ml}$ distilled water. After $24 \mathrm{~h}$, this mixture was transferred to a Clevenger type apparatus. After distillation, which lasted about $2 \mathrm{~h}$, the essential oil was obtained. The oil phase was isolated from the obtained solution. Sodium sulfate was used for dehydration.

\section{Bioassays and treatment}

\section{Toxicity tests}

After initial bracketing tests, three concentrations of 4, 6 and 8 percent, were selected for bioassay and evaluation of $\mathrm{LC}_{50}$ values, along with a control treated with methanol alone. In each experiment, 10 slugs were tested with 4 replicates per each concentration. Fresh leaves of radish, Rhaphanus satious (Cruciferae), were dipped in the different concentrations of $A$. annua essential oil for 30 seconds and allowed to air dry. The control leaves were treated with methanol alone and dried in the same way. The slugs were starved $4 \mathrm{~h}$ prior to the experiments and then were allowed to feed on two leaves treated with the different concentrations of $A$. annua essential oil for each replication. The lethal and sub lethal doses were estimated after $48 \mathrm{~h}$ using Polo-Pc software (LeOra software 1987).

\section{Biochemical analysis}

After the treatment, slugs were randomly selected, and their guts were removed by dissection in ice-cold saline buffer $(6 \mu$ mole/l $\mathrm{NaCl})$. The gut was rinsed in-cold diluted buffer, placed in a pre-cooled homogenizer. The homogenates from preparations were separately transferred to 1.5 centrifuge tubes and centrifuged at 13,000 $\mathrm{rpm}$ for $5 \mathrm{~min}$ at $4^{\circ} \mathrm{C}$. The supernatants were pooled and stored at $-20^{\circ} \mathrm{C}$ for subsequent analyses (Zibaee et al. 2008).

\section{Digestive enzyme assays}

The general protease amount of gut was determined using azocasein as a substrate (Elpidina et al. 2001). The reaction mixture was $30 \mu \mathrm{l}$ of $2 \%$ azocasein in a solution in $100 \mu \mathrm{l}$ of universal buffer and $30 \mu \mathrm{l}$ proteases. The reaction mixture was incubated at $30^{\circ} \mathrm{C}$ for $60 \mathrm{~min}$. Proteolysis was stopped by the addition of $150 \mu \mathrm{l}$ of $10 \%$ trichloroacetic acid (TCA), and the reaction mixture was centrifuged at $13000 \mathrm{rpm}$ for $10 \mathrm{~min}$. The $288 \mu \mathrm{l}$ volume of $2 \mathrm{~N}$ $\mathrm{NaOH}$ was added to the mixture and the absorbance was read at $440 \mathrm{~nm}$.

Lipase activity measurements were carried out as described by Tsujita et al. (1989). Ten $\mu$ l of gut tissue extract, $100 \mu \mathrm{l}$ of universal buffer solution $(1 \mathrm{M})(\mathrm{PH}=7.2)$, and $30 \mu \mathrm{l}$ of p-nitrophenyl butyrate $(27 \mathrm{mM})$ substrate, were incorporated, mixed thoroughly and incubated at $28^{\circ} \mathrm{C}$ for $10 \mathrm{~min}$. Next, $100 \mu \mathrm{l} \mathrm{NaOH}$ was added to each tube (the control and experimental samples). After $5 \mathrm{~min}$ the absorbance was read at 450 (405) $\mathrm{nm}$.

Amylase was assayed by the dinitrosalicylic acid (DNS) procedure (Bernfeld 1955) using 1\% soluble starch (Merck, Darmstadt, Germany) as a substrate. Ten microliters of the enzyme were incubated for $30 \mathrm{~min}$ at $37^{\circ} \mathrm{C}$ with $100 \mu$ universal buffer and $50 \mu$ l soluble starch. The reaction was stopped by the addition of $80 \mu \mathrm{l}$ DNS and heated in boiling water for $10 \mathrm{~min}$. DNS is a color reagent, hence the reducing groups released from starch by amylase were measured by the reduction of DNS. The boiling water stoped the amylase activity and catalyzes the reaction between DNS and the reducing groups of starch. Absorbance was then read at $540 \mathrm{~nm}$.

\section{Detoxifying enzymes}

The method of Bessy et al. (1946) was used for measuring alkaline phosphatase (ALP) and acid phosphatase (ACP) activity. The reaction mixture was $100 \mu \mathrm{l}$ of universal buffer, $30 \mu \mathrm{l}$ of related substrate (acidic for ACP, alkalic for ALP) and $20 \mu \mathrm{l}$ enzyme. This mixure was incubated for $30 \mathrm{~min}$, after that $50 \mu \mathrm{l} \mathrm{NaOH}(1 \mathrm{M})$ was added. Asorbance was read at $400 \mathrm{~nm}$.

The P450 activities were determined according to the method reported by Hansen and Hodgson (1971). One hundred microliters of $2 \mathrm{mM}$ p-nitroanisole solution and $90 \mathrm{ml}$ enzyme stock solution were added to each well of a microplate and mixed. After incubation for $2 \mathrm{~min}$ at $271^{\circ} \mathrm{C}$, the reaction was initiated by adding $10 \mathrm{ml}$ of 9.6 mM NADPH. Then, the optical density at $405 \mathrm{~nm}$ was immediately recorded at intervals of $25 \mathrm{~s}$ for $10 \mathrm{~min}$ using the microplate reader.

\section{Statistical analysis}

The lethal concentration was estimated by POLO-PC software (LeOra software 1987). All data were analyzed in a completely randomized design using SAS software and Tukey's studentized test was used for comparisons of means (SAS 1997).

\section{RESULTS}

The $\mathrm{LC}_{90}, \mathrm{LC}_{50}, \mathrm{LC}_{30}, \mathrm{LC}_{10}$ values, confidence limit (95\%) and regression slope at $48 \mathrm{~h}$ exposure to plant essential oil are shown in figure 1 . The $\mathrm{LC}_{50}$ value, confidence limit (95\%) at $48 \mathrm{~h}$ exposure to plant essential oil was $5.81 \%$. Results showed that the mortality was dosedependent. As can be seen in table 1 and figure 1, increasing concentration of plant extract exacerbate mortality.

The effect of $A$. annua on biochemical and metabolic events in this slug, is shown on table 2 and 3. Differences in lipase, amylase, protease between the control and treated slugs are shown on table 2 . The level of lipase in treated slugs was significantly enhanced 48 after treatment with $A$. annua and then was reduced $72 \mathrm{~h}$. In treated slugs, amylase was reduced $24 \mathrm{~h}$ after application of the essential oil but increased $72 \mathrm{~h}$ later. These alternations were significant compared with the control. The protease was significantly increased in treated slugs 24 and $48 \mathrm{~h}$ after treatment. 


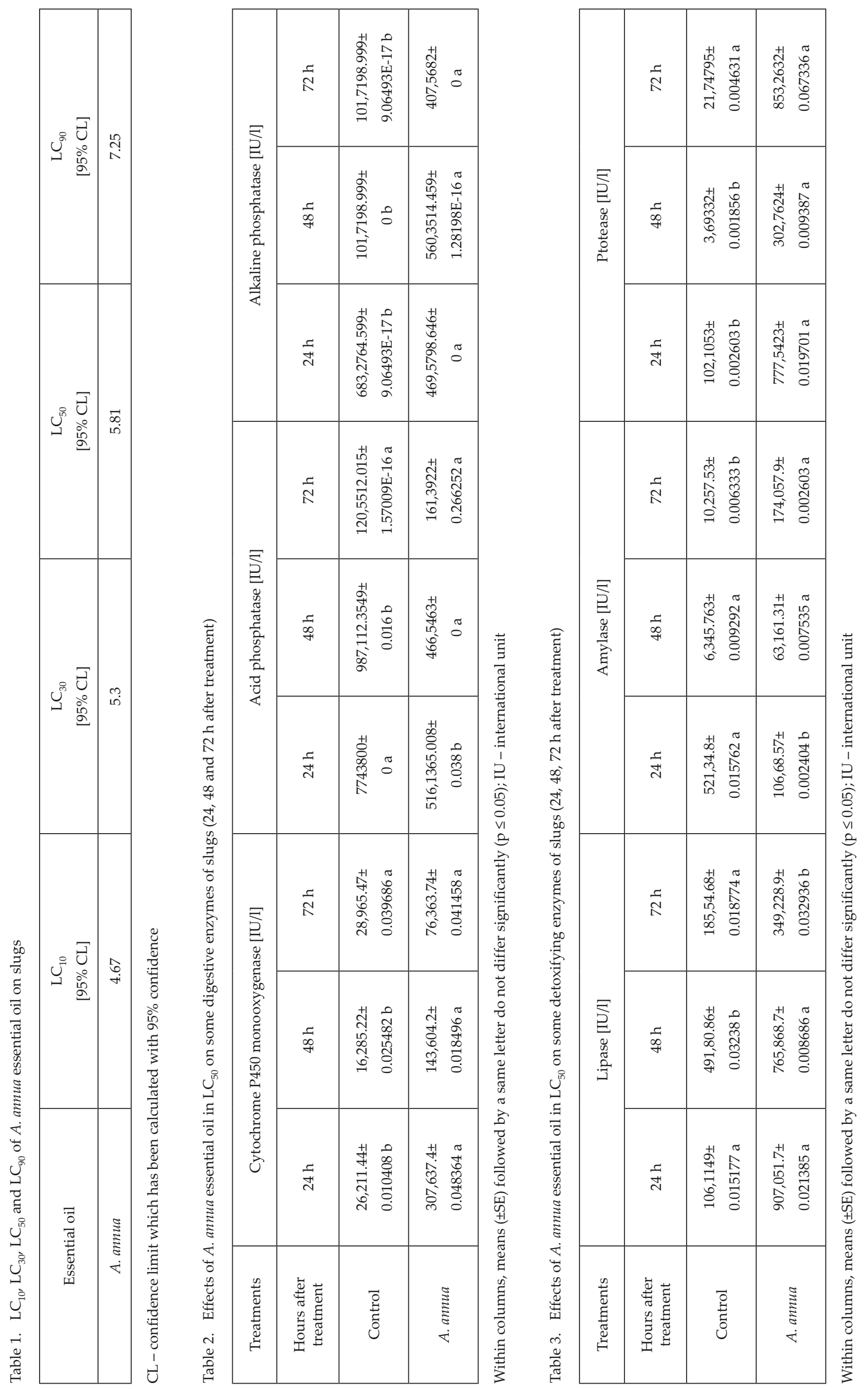




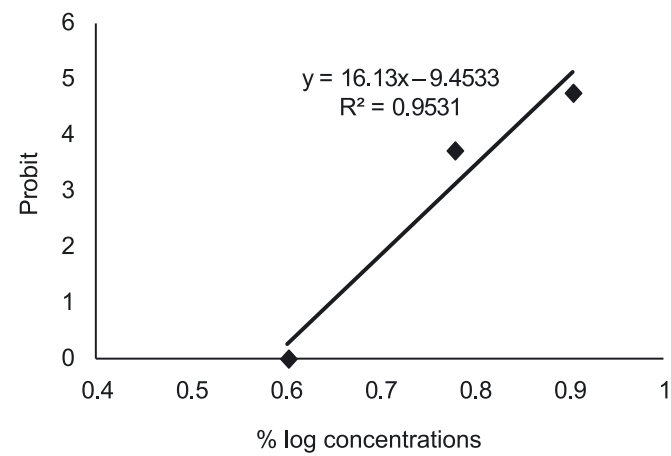

Fig. 1. The regression line of the mortality of $A$. agrestis by A. annua essential oil

Differences in detoxifying enzymes Cytochrome P450 monooxygenase, alkaline phosphatase (ALP), acid phosphatase $(\mathrm{ACP})$ between the control and treated slugs are shown in table 3. In treated animals, Cytochrome P450 monooxygenase was increased after 24 and $48 \mathrm{~h}$. Both ALP and ACP, were increased and were significant compared with the controls.

\section{DISSCUSION}

Essential oils are generally composed of complex mixtures of monoterpenes, biogenetically related phenols, and sesquiterpenes. Examples include: 1, 8-cineole, the major constituent of oils from rosemary (R. officinalis) and eucalyptus (Eucalyptus globus); eugenol from clove oil (Syzygium aromaticum); thymol from garden thyme (Thymus vulgaris); and menthol from various species of mint (Mentha species) (Isman 2006).

The enzyme lipase breaks carboxyl ester in triacylglycerols, phospholipids and galactolipids. This group of enzymes has a role in storage and mobilization of lipids. Lipases are also the building blocks for many physiological processes such as; growth, reproduction and defense against pathogens. The increase after $24 \mathrm{~h}$ in lipase in the present investigation, may be due to the use of storage lipids. The metabolic enzymes have a role in metabolizing toxic materials. The metabolic processes include oxidation and hydroxylation. Hence, these enzymes are concerned with the mode of action of pesticides and resistance to pesticides. Alpha-amylase is an enzyme hydrolyzing starch to maltose and glycogen to glucose. This enzyme was reduced $24 \mathrm{~h}$ after treatment with essential oil. Proteases are a group of enzymes that hydrolyze peptide bonds in proteins and convert them into their respective amino acids. This enzyme increased after 24 and $48 \mathrm{~h}$, significantly. We believe the increase in protease activity in the present study may be due to hydrolysis of stored proteins in this mollusk trying to compensate for the lack of proteins from food sources. Alkaline phosphatase, acid phosphatase are hydrolytic enzymes, which hydrolyse phosphomonoesters under acid or alkaline conditions, respectively. ALP is mainly found in the intestinal epithelium of animals and its primary function is to provide phosphate ions from mononucleotide and ribonucleo-proteins for a variety of metabolic processes. ALP is involved in the transphosphorylation reaction (Etebari et al. 2005). The present study showed that ACP activity decreased significantly after a $24 \mathrm{~h}$ post-treatment in all treatments, compared with the control. At the same time, the activity of this enzyme did not show a significant difference in slugs treated with essential oil or the control, 48 and $72 \mathrm{~h}$ after treatment. ALP activity after 24, 48 and $72 \mathrm{~h}$ was increased. Increased ALP and ACP activity level after treatment, compared to the control, may indicate the involvement of these enzymes in the detoxification processes. Acid phosphatase is a lysosomal enzyme dealing with digestion of foreign substances and bacteria inside the cells (Ham et al. 1979) and is involved in the defense mechanisms of both vertebrates and invertebrates (Cooper et al. 1976). In addition, the deterioration in the activity of alkaline phosphatese can occur in all types of liver diseases (Farkas et al. 2004).

Cytochrome P450 monooxygenase may have increased because of the detoxifying role of this enzyme. A. annua essential oil not only showed a toxicity effect but also had irreversible effects on biochemical metabolites, digestive and detoxifying enzymes. Thus, the biological processes of the slug were affected. The use of synthetic insecticides affects the environment and the food chain. While biological molluscicides having plant origins have little or no side effects on the environment and on the human food chain. Hence, it is worthwhile to search for new plants having environmently-friendly compounds.

\section{ACKNOWLEDGEMENTS}

Financial assistance from the Research Department of the University of Guilan for this research program is gratefully acknowledged. The authors would like to thank Mr. Ghasemi for his assistance.

\section{REFERENCES}

Ascher K.R.S. 1993. Non-conventional insecticidal effects of pesticides available from the neem tree, Azadirachta indica. Arch. Insect. Biochem. Physiol. 22 (3-4): 433-449.

Bernfeld P. 1955. Amylases, a and b. Methods Enzymol. 1: 149158.

Bessy O.A., Lowry O.H., Brock M.J. 1946. A method for the rapid determination of alkaline phosphate with five cubic millimeters of serum. J. Biol. Chem. 164 (1): 321-329.

Bhakuni R.S., Jain D.C., Sharma R.P., Kumar S. 2001. Secondary metabolites of Artemisia annua and their biological activity. Curr. Sci. 80 (1): 35-49.

Cooper E.L. 1976. Comparative Immunology. Prentice-Hall, INC., Englewood Cliffs. New Jersy, USA, 338 pp.

Elpidina E.N., Vinokurov K.S., Gromenko V.A., Rudenskaya Y.A., Dunaevsky Y.E., Zhuzhikov D.P. 2001. Compartmentalization of proteinases and amylases in Nauphoeta cinerea Midgut. Arch. Insect Biochem. Physiol. 48 (4): 206-216.

Etebari K., Mirhoseini S.Z., Matindoost L. 2005. A study on intraspecific biodiversity of eight groups of silkworm (Bombyx mori) by biochemical markers. Insect. Sci. 12 (2): 87-94.

Farkas J. Farkas P., Hyde D. 2004. Liver and gastroenterology tests. p. 330-336. In: "Basic Skills in Interpreting Laboratory Data" (M. Lee, ed.). 3rd ed. Amer. Soc. Helth-Syst. Pharmacists, Bethesda, Maryland, USA, 618 pp. 
Glen D. M., Wiltshire C.W., Butler R.C. 1991. Slug population changes following molluscicide treatment in relation to distance from the edge of treated area. Crop Prot. 10 (5): 408-412.

Ham A.W., Gomak D.H. 1979. Histology. JB. Lippincott Company, Philadelphia and Toronto, $764 \mathrm{pp}$.

Hansen L.G., Hodgson E. 1971. Biochemical characteristics of microsomes: N-and Odemethylation. Biochem. Pharmac. 20 (7): 1569-1578

Isman M.B. 1999. Pesticides based on plant essential oils. Pesticide 10: 68-72.

Isman M.B. 2006. Botanical insecticides, deterrents, and repellents in modern agriculture and an increasingly regulated world. Ann. Rev. Entomol. 51: 45-66.

Jalali J., Arbab A., Aliakbar A. 2005. The efficacy of Aqueous plant extracts of wormwood and dwarf elder against elm leaf beetle Xanthogaleruca luteola Mull. (Coleoptera: Chrysomelidae). Agri. Sci. Knowl. 15: 115-120.

Jalali J., Haghigian F., Aliakber A. 2002. Comparative insecticidal efficacy of Artemisia annua L. and Sambucus ebulus L. extracts on Tribolium confusum Duv. Iranian J. Agri. Sci. 34 (1) 313-319.
Khanjani M. 2005. Vegetable Pests in Iran. Bu-Ali Sina University Publications, $719 \mathrm{pp}$.

LeOra software. 1987. Polo-Pc: A User Guide to Probit or Logit Analysis. LeOra Software, Berkeley, California, 22 pp.

Rao P.J., Maheshkumar K., Singh S., Subrah B.M. 1999. Effects of Artemisia annua oil on development and reproduction of Dysdercus koengii F. (Hem.: Pyrrhocoridae). J. Appl. Entomol. 123 (5): 315-318.

SAS institute. 1997. SAS/STAT user's guide for personal computers. SAS Institute, Cary, NC, 128 pp.

Schmutterer H. 1990. Properties and potential of natural pesticides from the neem tree. Annu. Rev. Entomol. 35: 271-298.

Schmutterer H. 1995. The Neem Tree Azadirachta indica and Other Meliaceus Plants; Sources of Unique Natural Products for Integrated Pest Management, Medicine, Industry and Other Purposes. VCH publishers, Weinheim, Germany, 696 pp.

Tsujita T., Ninomiya H., Okuda H. 1989. P-nitrophenyl butyrate hydrolyzing activity of hormone-sensitive lipase from bovine adipose tissue. J. Lipid. Res. 30 (7): 997-1004.

Zibaee A., Bandani A.R., Ramzi S. 2008. Lipase and invertase activities in midgut and salivary glands of Chilo suppressalis (Walker Lepidoptera, Pyralidae), rice stem borer. Inv. Surv. J. 5: 180-189. 